\title{
Influence of farmed pearl oysters and associated biofouling communities on nutrient regeneration in lagoons of French Polynesia
}

\author{
Elise Lacoste ${ }^{1}$, Yannick Gueguen², Gilles Le Moullac ${ }^{2}$, Manaarii Sham Koua ${ }^{2}$, \\ Nabila Gaertner-Mazouni ${ }^{1, *}$ \\ ${ }^{1}$ Université de la Polynésie Française, Ecosystèmes Insulaires Océaniens, UMR 241, BP 6570, 98702 Faa'a, Tahiti, \\ French Polynesia \\ ${ }^{2}$ Institut Français de Recherche pour l'Exploitation de la Mer (IFREMER), Ecosystèmes Insulaires Océaniens, UMR 241, \\ BP 7004, Taravao 98719, French Polynesia
}

\begin{abstract}
Bivalve cultivation can significantly contribute to nutrient cycling in semi-enclosed ecosystems. We investigated the influence of suspended pearl oyster culture on nutrient regeneration in the water column of 3 oligotrophic lagoons in French Polynesia. The aim of this first study performed in a tropical area was to assess the seasonal variability of nutrient fluxes and to quantify the contribution of biofouling communities. In situ metabolic enclosure systems were used to measure nutrient uptake or release by 'cultivation units' (i.e. 4 pearl oysters with or without associated biofouling). In all 3 study lagoons (Tahiti, Mangareva, Ahe), nutrient fluxes produced by pearl oyster and associated biofouling communities (CR units) were 4- to 6-fold higher than those measured for cleaned pearl oysters. CR units can release dissolved inorganic nitrogen and soluble reactive phosphorus in the water column at a rate of 200 and $50 \mu \mathrm{mol} \mathrm{h}^{-1}$, respectively. Trophic level and composition of biofouling communities may explain the variations of fluxes observed between the different islands. At the pearl farm scale (Ahe), pearl oyster long-lines may supply $70 \%$ of the inorganic nitrogen demand for primary production, with biofouling communities accounting for $60 \%$ of the total nutrient release. Pearl oyster culture enhances nutrient availability and alters stoichiometry, which can strongly modify the dynamics of the planktonic ecosystem.
\end{abstract}

KEY WORDS: Pearl oysters $\cdot$ Biofouling $\cdot$ Nutrient flux $\cdot$ Aquaculture impact

\section{INTRODUCTION}

The intensive development of bivalve aquaculture results in major alterations of ecosystem processes, including an impact on benthic-pelagic coupling (sedimentation and remineralization) (Crawford et al. 2003, Giles et al. 2006, Mitchell 2006) and nutrient regeneration in the water column through bivalve excretion (Leblanc et al. 2003, Mazouni 2004, Nizzoli et al. 2005). Under nutrient-limiting conditions, it is argued that such enhancement of nutrient cycling may stimulate primary production (Asmus \& Asmus 1991, Dame \& Libes 1993). The influence of bivalve

*Corresponding author: nabila.gaertner-mazouni@upf.pf cultivation on nutrient cycling is highly variable depending on the commercial species and/or cultivation systems considered. It may also vary seasonally (Picot et al. 1990, Bacher et al. 1995, Newell 2004) or according to the composition of the whole filter feeder community, including biofouling organisms which develop on infrastructures and bivalve shells (Mazouni et al. 2001, Richard et al. 2006, Jansen et al. 2011). Whereas the influence of bivalve aquaculture on ecosystem processes has been widely investigated for temperate ecosystems (see the reviews of Prins et al. 1997, Cranford et al. 2003, Newell 2004, Dumbauld et al. 2009, Forrest et al. 2009), similar studies on

(C) The authors 2014. Open Access under Creative Commons by Attribution Licence. Use, distribution and reproduction are unrestricted. Authors and original publication must be credited. 
tropical ecosystems remain very scarce. With the extensive development of aquaculture in these areas, however, there will be increasing concern about the environmental impact of this industry.

In French Polynesia, aquaculture is based on the production of the pearl oyster Pinctada margaritifera, cultivated for its black pearls. Millions of pearl oysters are artificially hanging on long-lines in the water column, which may strongly alter the dynamics of nutrient and biological production of lagoons. In these oligotrophic areas, primary production is known to be mainly limited by nitrogen (Dufour \& Berland 1999, Dufour et al. 2001, Charpy et al. 2012). External nitrogen inputs from ocean and atmospheric dinitrogen fixation (i.e. diazotrophy) are the main sources of nitrogen identified, providing around 10 and $25 \%$, respectively, of the nitrogen demand for primary production (Charpy-Roubaud et al. 1990, 2001). The indirect influence of pearl oyster cultivation on nutrient regeneration has only recently been investigated with the study of Gaertner-Mazouni et al. (2012). These authors reported that benthic nitrogen fluxes were higher in areas below pearl oysters than in noncultivated areas and could contribute up to $28 \%$ of the nitrogen demand for primary production. While in suspended culture, pelagic nutrient regeneration may outweigh benthic remineralization (Mazouni et al. 2001, Nizzoli et al. 2005), and it is expected that pearl oyster culture may have a strong influence on nutrient fluxes in the water column. Information is lacking on this point, and the factors that may drive nutrient exchanges in the water column are unknown.

In this context, the aim of the present work was to explore and quantify the contribution of pearl oyster long-lines on nutrient regeneration in the water column. Pearl oyster culture was considered as a whole, including biofouling communities, which may represent considerable biomass in pearl farms. We performed an in situ study to (1) determine the temporal variability of nutrient fluxes induced by pearl oyster culture, (2) assess the potential influence of the environment on flux variability and (3) quantify the contribution of biofouling communities to nutrient renewal in the water column. Our goal was also to highlight the role that pearl oyster culture can play in the overall nutrient budget in these exploited lagoons.

\section{MATERIALS AND METHODS}

\section{Study implementation}

Pearl oyster culture in French Polynesia extends across 27 islands in 3 archipelagos and is distributed over a 2 million $\mathrm{km}^{2}$ area with high geomorphological, hydrological and biological diversity.

To achieve the different aims of the study, experiments were carried out in 3 lagoons in French Polynesia (Fig. 1). The first experiment, which assessed the annual variability of nutrient release by the pearl

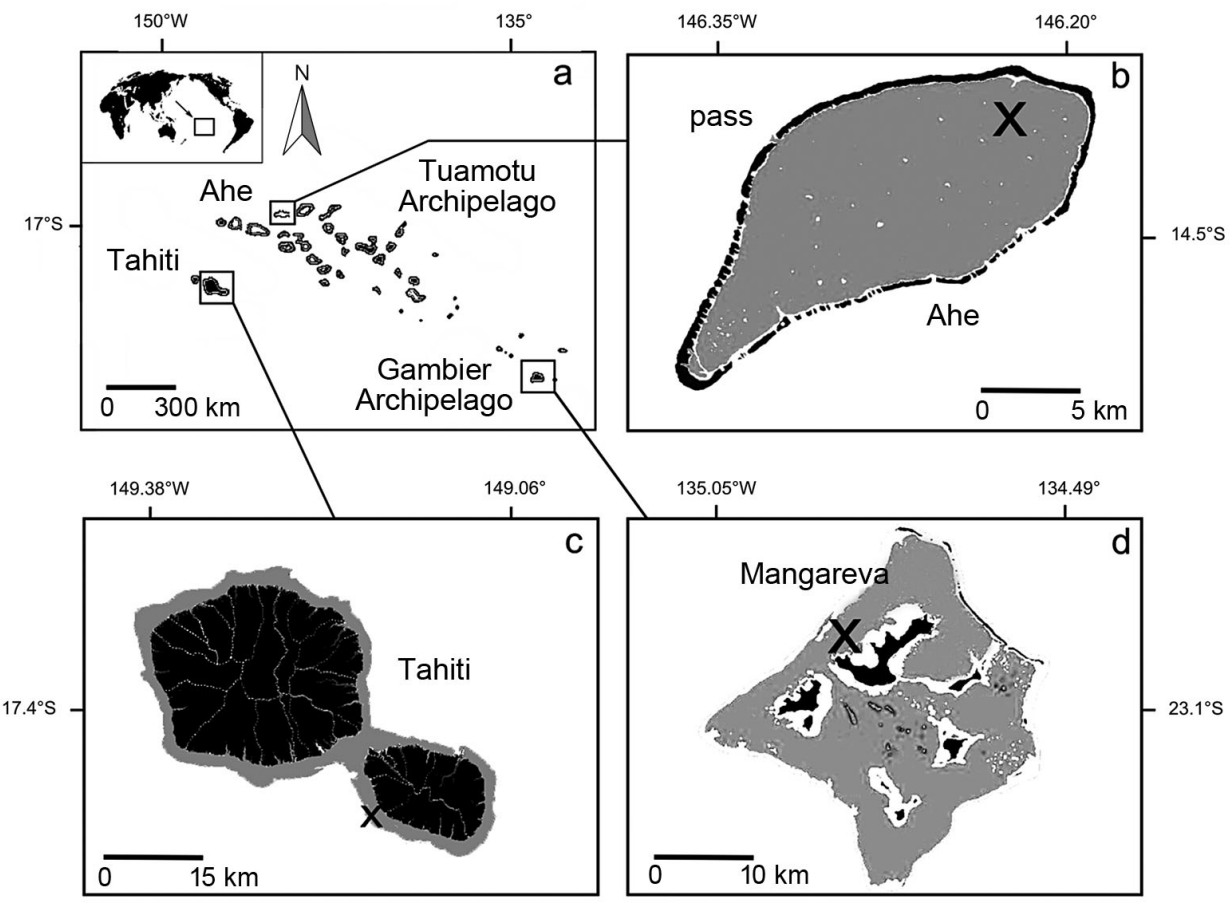

Fig. 1. Location of the 3 islands in French Polynesia (a). Crosses show the experimental sites in the lagoons (shaded grey) of Ahe (b), Tahiti (c) and Mangareva (d) 
oyster culture, was implemented in Tahiti. At Tahiti, water temperatures follow a seasonal pattern and environmental conditions (e.g. temperature range and chl a concentration) are intermediate among the 3 lagoons studied. Ease of access was an advantage for conducting monthly sampling over an annual cycle. Since biofouling development in Tahiti was not expected to be high, additional experiments were carried out at 2 other sites to quantify the impact of biofouling communities on nutrient fluxes. Mangareva and Ahe, located in the Tuamotu-Gambier Archipelago (Fig. 1), were chosen because of their extensive pearl farming industry (Talvard 2011) and because they experience high levels of biofouling.

\section{Study sites}

Geographical and environmental information on the 3 study sites is summarized in Fig. 1 and Table 1. Tahiti is the main island of French Polynesia and corresponds to a reef system. The experiment took place in the southwestern part of the lagoon (Vairao), where the depth is around $25 \mathrm{~m}$ and the proximity of small rivers occasions terrestrial inputs. Mangareva, the main island of the Gambier Archipelago (Fig. 1d), is located $1700 \mathrm{~km}$ southeast of Tahiti. Because of its latitudinal position, high thermal amplitude is observed in this area, and seawater temperature can fall by up to $22^{\circ} \mathrm{C}$. In 2011, 102 pearl farms, covering a surface area of $1260 \mathrm{ha}$, were counted in this archipelago (Talvard 2011). The experiment took place in the western part of the island, where numerous pearl farms are established. Ahe is a small, deep atoll lagoon (average depth $41 \mathrm{~m}$ ) located in the northern part of the Tuamotu Archipelago, $500 \mathrm{~km}$ northeast of Tahiti. Only one inlet (pass) allows exchanges with the ocean in this semi-enclosed atoll, which is characterized by a high annual average water temperature with low seasonal variations (Table 1). Presently, approximately $11 \%$ of the lagoon surface area is used for the farming of pearl oysters. Experiments took place in the northern part of the lagoon.

\section{Experimental design}

In Tahiti, monthly sampling was conducted over 14 mo, from April 2011 to May 2012. Five hundred 2-yr-old pearl oysters (mean height: $80.6 \pm 9.1 \mathrm{~mm}$ ) were transferred from a Tuamotu atoll farm (Takapoto) and reared on an experimental long-line in the lagoon near the IFREMER marine institute. Pearl oysters were maintained in traditional systems consisting of suspended long-lines immersed at $7 \mathrm{~m}$ depth, with pearl oysters 'ear-hanging' in pairs on downlines in groups of 20 per rope. Biofouling at this site was expected to be characterized by an accumulation of organic matter from the proximity of rivers rather than by the development of macrofouling communities and, thus, was not quantified. To test the seasonal variations of fluxes considering the whole of the communities on ropes (including organisms and organic matter), half of the experimental ropes were never cleaned during the entire period of the experiment (colonized ropes). To distinguish the role of biofouling from that of pearl oysters in total fluxes, flux measurements from a group of cleaned pearl oysters were recorded regularly. Those pearl oysters were cleaned every 3 mo, at least $24 \mathrm{~h}$ before experimentation, using a pressure washer.

Every month, 3 sections of colonized ropes, including 4 pearl oysters per bag and associated fauna and organic matter (referred to hereafter as CR units), were randomly collected on the experimental longline for flux measurement. This protocol was repeated every 3 mo for pearl oysters which had been cleaned previously (referred to hereafter as PO units).

At the 2 other sites, pearl oysters used for experimentation originated from local pearl farms, where pearl oysters are reared in nets (Mangareva) or 'ear-hung' on ropes (Ahe) and attached to long-lines

Table 1. Characteristics of the 3 studied lagoons. $\mathrm{AD}=$ average depth; $\mathrm{LA}=$ lagoon area; NI = number of inlets to the ocean. -: not applicable because it is a reef system

\begin{tabular}{|c|c|c|c|c|c|c|c|c|}
\hline Site & Latitude & Longitude & $\mathrm{LA}\left(\mathrm{km}^{2}\right)$ & NI & $\mathrm{AD}(\mathrm{m})$ & Temperature $\left({ }^{\circ} \mathrm{C}\right)$ & Chl a $\left(\mu g l^{-1}\right)$ & Source \\
\hline Ahe & $14^{\circ} 29^{\prime} \mathrm{S}$ & $146^{\circ} 18^{\prime} \mathrm{W}$ & 142 & 1 & 41 & $27.3-29.2$ & $0.22-1.31$ & $\begin{array}{l}\text { Bouvy et al. (2012) } \\
\text { Fournier et al. (2012) }\end{array}$ \\
\hline Mangareva & $23^{\circ} 07^{\prime} \mathrm{S}$ & $134^{\circ} 52^{\prime} \mathrm{W}$ & 500 & open & 14 & $21.3-28.8$ & $0.67-1.27$ & $\begin{array}{l}\text { Pirazzoli (1984) } \\
\text { Pouvreau \& Prasil (2001) } \\
\text { This study }\end{array}$ \\
\hline Tahiti & $17^{\circ} 80^{\prime} \mathrm{S}$ & $149^{\circ} 30^{\prime} \mathrm{W}$ & - & - & 25 & $24.9-29.5$ & $0.24-1.87$ & $\begin{array}{l}\text { Pouvreau \& Prasil (2001) } \\
\text { This study }\end{array}$ \\
\hline
\end{tabular}


suspended at a depth of 6 to $10 \mathrm{~m}$. Pearl oysters are usually cleaned of epibionts by farmers every 3 to 6 mo using pressurized seawater. Surveys were conducted in May 2012 in Mangareva and in May 2013 in Ahe. Reared pearl oysters were collected at each site by SCUBA divers. Groups of 4 (Mangareva) to 6 (Ahe) pearl oysters and their associated biofouling communities were used for flux measurements. To test the effect of biofouling development (biomass and composition of biofouling communities), nutrient fluxes were measured for pearl oysters which had been colonized during 3 (Ahe and Mangareva) and 6 mo (Mangareva) (referred to hereafter as CR3 and CR6 units, respectively). After flux experiments, biofouling from each unit was collected for measurements (weight and taxonomic identification). Pearl oysters were then thoroughly cleaned and re-used (24 h later) to measure nutrient fluxes without biofouling (PO units).

For all of the sites, the pearl oysters used in experiments were measured and weighed (total wet weight and flesh wet weight).

\section{Metabolic enclosure system for in situ flux measurement}

All experiments were carried out by SCUBA diving at $7 \mathrm{~m}$ depth near the cultivation sites. The system used for nutrient flux measurement is referred to as the metabolic enclosure system (MES, Fig. 2) (Mazouni et al. 1998). Time of incubation at each site ( 1 to $3 \mathrm{~h}$ ) was selected after preliminary measurements to allow recording of nitrogen fluxes on the linear phase and to prevent a drop below $30 \%$ of the

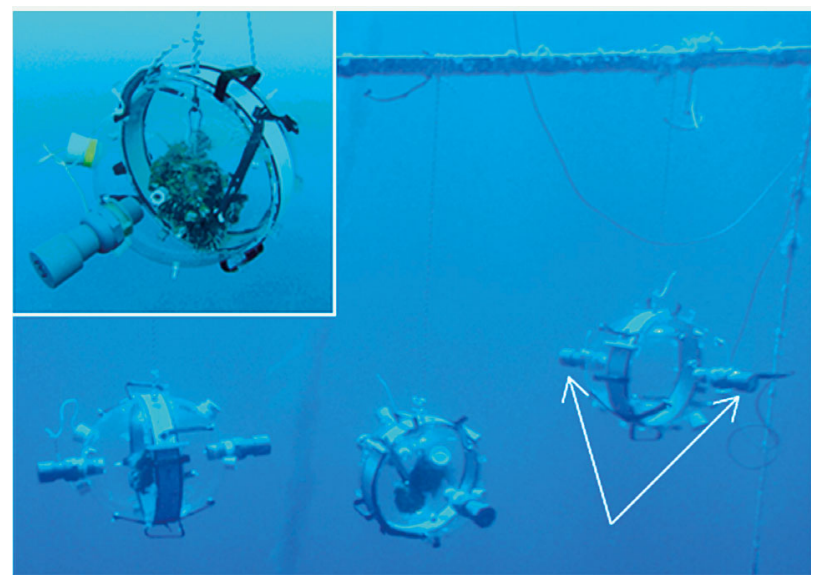

Fig. 2. In situ metabolic enclosure system (MES) used for flux measurements. Magnetic stirrers (arrows) were used on each side of the MES to gently homogenize the water initial concentration of oxygen, which may alter bivalve metabolism (Le Moullac et al. 2007, Sussarellu et al. 2010). Temperature was recorded during the experiment to check for any changes which may have influenced pearl oyster physiology (Saucedo et al. 2004, Mondal 2006). For each experiment, 4 MES were installed simultaneously, 3 containing organisms (CR or PO units) and 1 empty used as a control. During incubation, $180 \mathrm{ml}$ of water was sampled in each MES at regular intervals to estimate the changes in nutrient concentration over time. Fluxes were calculated from the difference between initial and final concentrations of nutrient and related to the chamber volume. Final fluxes were obtained by subtracting the value of fluxes in the control MES corresponding to the natural fluxes in the water column.

\section{Laboratory protocols}

\section{Water column characteristics}

During each experiment, water was sampled at long-line sites for nutrient and chlorophyll analysis. Volumes of $500 \mathrm{ml}$ of water were filtered after sampling on Whatman GF/F to measure chl a contained in total phytoplankton. Chl a was extracted with $96 \%$ ethanol and analyzed after $6 \mathrm{~h}$ using the fluorometric procedure described in Welschmeyer (1994) on a TD 700 fluorometer (Turner Designs) calibrated with pure chl a standard (Sigma). Chl a concentration was used as a proxy for phytoplankton biomass. Nutrient concentrations were analyzed using the method described below. Temperature was recorded for each specific experiment near the experimental system with a multi-parameter probe (YSI ProOdo).

\section{Nutrient analysis}

Water samples $(40 \mathrm{ml})$ were collected; immediately fixed in the field; and stored in a dry, cool place for $\mathrm{NH}_{4}$ analysis. $\mathrm{NH}_{4}$ concentration was determined manually by fluorometry with a Turner TD-700 using the ortho-phthaldialdehyde method as described in Holmes et al. (1999). This measurement was performed within $10 \mathrm{~h}$ post-sampling at the field laboratory. A second set of samples $(20 \mathrm{ml})$ was fixed using $\mathrm{HgCl}_{2}$ (Kattner 1999) and kept in the refrigerator prior to nitrate and nitrite $\left(\mathrm{NO}_{\mathrm{X}}\right)$ and soluble reactive phosphorus (SRP) analyses. These samples were analyzed by colorimetry using a Technicon AutoAnalyzer III system (Aminot \& Kérouel 2004). 
Table 2. ANOVA testing the effect of time and treatment (colonized ropes and cleaned pearl oysters) on dissolved inorganic nitrogen (DIN) and soluble reactive phosphorus (SRP) fluxes. Bold values are significant at $p<0.05$. DIN flux: $\ln (x+4) ;$ SRP flux: $\ln (x+2)$

\begin{tabular}{|c|c|c|c|c|c|c|c|c|}
\hline \multirow{2}{*}{ Source of variation } & \multicolumn{4}{|c|}{-DIN flux - } & \multicolumn{4}{|c|}{ - SRP flux } \\
\hline & df & MS & $F$ & $\mathrm{p}$ & df & MS & $F$ & $\mathrm{p}$ \\
\hline Treatment & 1 & 0.95 & 41.4 & $<0.001$ & 1 & 0.09 & 12.15 & $<0.005$ \\
\hline Month & 4 & 0.37 & 15.99 & $<0.001$ & 4 & 0.05 & 6.37 & $<0.005$ \\
\hline Treatment $\times$ Month & 4 & 0.19 & 8.55 & $<0.001$ & 4 & 0.04 & 4.5 & $<0.005$ \\
\hline Residuals & 18 & 0.02 & & & 19 & 0.01 & & \\
\hline
\end{tabular}

\section{RESULTS}

\section{Intra-annual variations of fluxes}

\section{Environmental conditions}

A strong seasonal pattern of water column characteristics was evidenced during the annual monitoring in Tahiti (Fig. 3). The study period began in April 2011, which corresponds to the beginning of the dry

\section{Data 'standardization' and statistical analysis}

Flux mean and standard deviation (SD) values were based on fluxes from replicates $(n=3)$ of units for each date. $\mathrm{NH}_{4}$ and $\mathrm{NO}_{\mathrm{X}}$ fluxes were added to estimate the total dissolved inorganic nitrogen (DIN) fluxes.

In Tahiti, ANOVA, which tested the effect of treatment (CR and PO units) and date on flesh wet weight of pearl oysters, revealed that date was the only significant source of variation $(\mathrm{p}<0.001)$. In experimental units, the mean $( \pm \mathrm{SD})$ biomass of pearl oysters (expressed in flesh wet weight) varied from 15.0 $\pm 3.6 \mathrm{~g}$ at the beginning of experimentation to $32.2 \pm$ $6.8 \mathrm{~g}$ at the end, with no difference between CR and PO units ( $p=0.923)$. Based on this result, all fluxes were thus presented per unit of 4 pearl oysters with biofouling (CR units) or without (PO units). This allows comparisons between the dates during which fluxes were measured for the 2 treatments (May, August and November 2011 and February and May 2012).

Effects of time and treatment on fluxes were tested using 2-way ANOVA. All data were graphically assessed for normality and homogeneity of residuals (Faraway 2002), and transformations were performed when necessary (Table 2). In the case of significant difference $(\mathrm{p}<0.05)$, a posteriori comparison of the means was performed using a post hoc Tukey's test (Tukey's HSD) (Sokal \& Rolf 1995). Correlations between nutrient fluxes and environmental variables were explored for each treatment with Spearman's rank correlation test, as environmental variables were not normally distributed.

In Ahe and Mangareva, treatment effect (i.e. biofouling) on nutrient fluxes was tested using Student's $t$-test. Fluxes in these 2 sites were also expressed per unit of 4 pearl oysters, and contribution of biofouling communities to fluxes was calculated using fluxes measured for PO units. season at tropical latitudes; the wet period starts in November. During the dry period, all variables showed values below their calculated average,

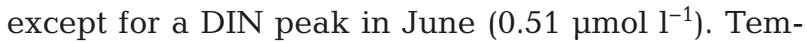
perature varied between 26.3 and $27.5^{\circ} \mathrm{C}$ for this period, and the minimum values of chl $a$ and DIN were recorded as $0.3 \mu \mathrm{g}^{-1}$ and $0.19 \mu \mathrm{mol} \mathrm{l}^{-1}$, respectively. From December, apart from the sudden drop of SRP in February, all parameters showed values above their calculated average (Fig. 3). Temperature reached its maximum value $\left(>28.5^{\circ} \mathrm{C}\right)$ from February to April 2012. Chl a showed values around the mean $\left(0.72 \mu \mathrm{g} \mathrm{l}^{-1}\right)$, except for a high peak in January $\left(1.87 \mu \mathrm{g} \mathrm{l}^{-1}\right)$. High values of DIN from February 2012 (maximum value of $0.57 \mu \mathrm{mol} \mathrm{l}^{-1}$ in March) were mainly due to an increase of $\mathrm{NO}_{\mathrm{X}}$ concentration in

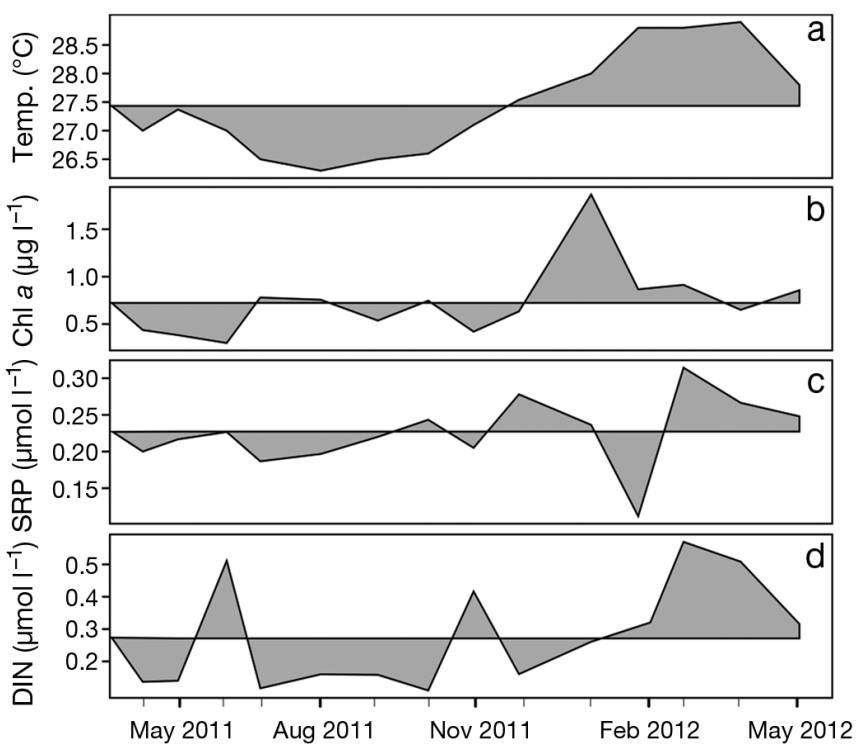

Fig. 3. Environmental parameters monitored in Tahiti between April 2011 and May 2012. (a) Temperature; (b) chl a; (c) soluble reactive phosphorus (SRP); (d) dissolved inorganic nitrogen (DIN). Horizontal line represents the annual mean, and shaded areas above or below the continuous line indicate periods with values higher or lower than the mean 
the water column. $\mathrm{NO}_{\mathrm{X}}$ always accounted for at least $60 \%$ of the DIN concentration except in January $2012(48 \%)$, and the N:P ratio average for the whole period was 1.27. For the same period (April and May), the year 2012 was warmer than 2011. Regular rain events were observed in June and November 2011 and during 2012. This rainfall coincided with an increase of DIN $\left(\mathrm{NO}_{\mathrm{X}}>\mathrm{NH}_{4}\right)$ concentration in the lagoon.

\section{Nutrient fluxes}

Fluxes of CR units followed the same pattern for DIN and SRP (Fig. 4). Fluxes were low during the first 9 mo, increased between January and March 2012 and finally decreased in April to May 2012. DIN fluxes produced by $\mathrm{CR}$ units ranged from (mean \pm SD) $3.01 \pm 1.53 \mu \mathrm{mol} \mathrm{h}{ }^{-1}$ in August 2011 to $35.02 \pm$ $16.51 \mu \mathrm{mol} \mathrm{h}{ }^{-1}$ in January 2012, and $\mathrm{NH}_{4}$ contribution to total DIN flux varied between 60 and $100 \%$. For SRP fluxes, values varied from $-0.64 \pm 0.81 \mu \mathrm{mol}$ $\mathrm{h}^{-1}$ in April 2011 to $3.05 \pm 1.22 \mu \mathrm{mol} \mathrm{h} \mathrm{h}^{-1}$ in March 2012. Except in April 2011, SRP fluxes by CR units were always positive, indicating a release (production) in the water column.

For PO units, DIN was released toward the water column at a maximum rate of (mean $\pm \mathrm{SD}$ ) $6.78 \pm 1.78$ $\mu \mathrm{mol} \mathrm{h}^{-1}$ per unit, except in August 2011 during which a DIN uptake was measured (-1.28 \pm 2.23 $\mu \mathrm{mol} \mathrm{h} \mathrm{h}^{-1}$ ). For these units, $\mathrm{NH}_{4}$ accounted for almost $100 \%$ of the total DIN fluxes. The SRP fluxes varied between $-0.68 \pm 0.22$ and $1.27 \pm 0.76 \mu \mathrm{mol} \mathrm{h} \mathrm{h}^{-1}$. Pearl oyster biomass in PO units had no effect either on DIN fluxes $(t=0.35$, $\mathrm{df}=11, \mathrm{p}>0.1)$ or on SRP fluxes $(t=0.39$, df $=12, \mathrm{p}>0.1)$. When expressed in flesh dry weight, $\mathrm{NH}_{4}$ fluxes of a clean pearl oyster in our study varied from $-0.1 \pm 0.17$ to $0.83 \pm 0.17 \mu \mathrm{mol}$ $\mathrm{g}^{-1} \mathrm{~h}^{-1}$.

Treatment, date and the interaction of both had a significant effect on DIN and SRP fluxes (Table 2). After Tukeys' multiple comparison test, it appeared that fluxes produced by CR units were significantly higher than those of PO units in February and May 2012 for DIN and in February 2012 for SRP. DIN and SRP fluxes measured for PO units were not significantly different between dates.

Exploration of correlations between fluxes of PO units and environmental variables did not show any significant correlation (Spearman's test, $\mathrm{p}>0.1$ ). Conversely, for CR units, several correlations were found between environmental parameters and nutrient fluxes. DIN fluxes were correlated with tempera-
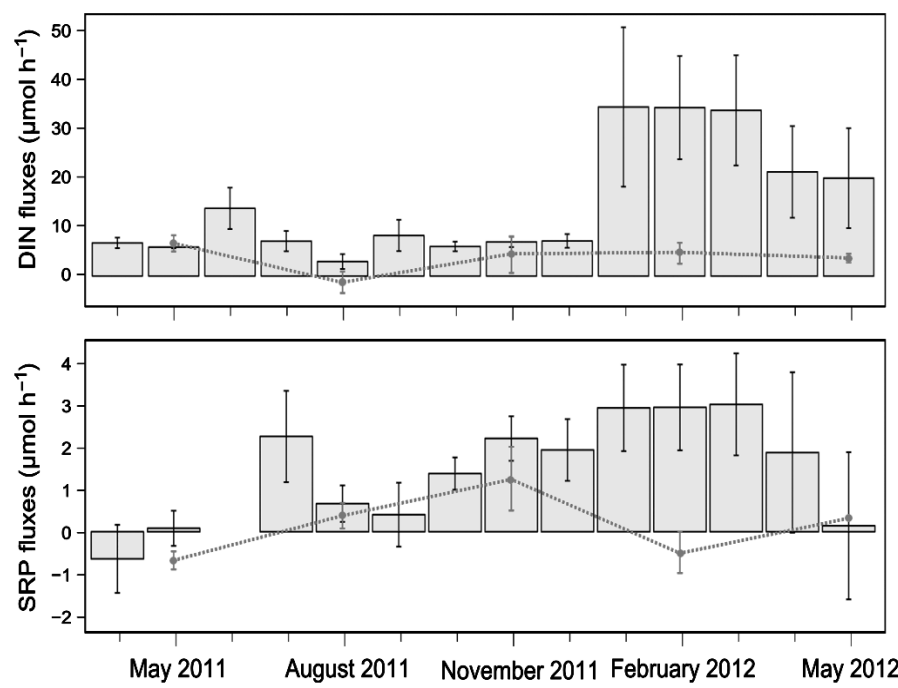

Fig. 4. Nutrient fluxes (mean $\pm \mathrm{SD}$ ) measured during the whole period in Tahiti for each treatment. Bars: units of colonized ropes $(\mathrm{CR})$; grey dots connected with dotted line for more clarity: units of clean pearl oysters (PO). Abscissa indicates months during which fluxes were recorded for both $\mathrm{CR}$ and PO units. DIN = dissolved inorganic nitrogen; $\mathrm{SRP}=$ soluble reactive phosphorus

ture $(\rho=0.73, p<0.005)$, chl a $(\rho=0.56, p<0.05)$ and DIN concentration in the water column $(\rho=0.64, p<$ 0.05), and SRP fluxes were correlated with chl a concentration $(\rho=0.60, p<0.05)$.

\section{Nutrient fluxes recorded in Ahe and Mangareva}

Environmental conditions and biofouling communities

During experiments performed in Ahe and Mangareva, environmental characteristics recorded were in agreement with the few values reported in the literature (Tables 1 \& 3). In May 2013, temperature in Ahe was in the upper range of reported values, whereas chl a concentration was intermediate. Temperature for the same season in Mangareva was almost $3^{\circ} \mathrm{C}$ less than that in Ahe, and chl a concentration was twice as much. $\mathrm{NH}_{4}$ concentration represented 40 and $30 \%$ of the total DIN concentration in Ahe and Mangareva, respectively, and the N:P ratio was 0.81 and 6.41 , respectively.

Details on pearl oyster units used for flux measurement are reported in Table 3. Epibiont weights in CR3 units were equivalent in Ahe and Mangareva, but their species compositions were not similar. In Ahe, the biofouling community was dominated by the presence of bivalves, especially Pinctada maculata but also Isognomon sp., Chama pacifica and Saccostrea sp. The ascidian Didemnum sp. was much 
Table 3. Water column characteristics and information about units of clean pearl oysters (PO units) and biofouling communities on colonized pearl oyster ropes (CR units) in Ahe and Mangareva. CT = colonization time; DIN = dissolved inorganic nitrogen; FWW = individual mean flesh wet weight; SRP = soluble reactive phosphorus; TWW = total wet weight in each unit

\begin{tabular}{|c|c|c|c|c|c|c|c|c|c|c|}
\hline \multirow[t]{2}{*}{ Site } & \multirow[t]{2}{*}{ Date } & \multicolumn{4}{|c|}{$\longrightarrow$ Environment } & \multicolumn{3}{|c|}{$\longrightarrow$ PO units $\longrightarrow$} & \multicolumn{2}{|c|}{ CR units -} \\
\hline & & $\begin{array}{l}\text { Temperature } \\
\left({ }^{\circ} \mathrm{C}\right)\end{array}$ & $\begin{array}{c}\text { Chl a } \\
\left(\mu g l^{-1}\right)\end{array}$ & $\begin{array}{c}\text { DIN } \\
\left(\mu \mathrm{mol} \mathrm{l} l^{-1}\right)\end{array}$ & $\begin{array}{c}\text { SRP } \\
\left(\mu \mathrm{mol} \mathrm{l} l^{-1}\right)\end{array}$ & $\begin{array}{l}\text { Age } \\
(\mathrm{mo})\end{array}$ & $\begin{array}{l}\text { FWW } \\
\text { (g) }\end{array}$ & $\begin{array}{c}\text { TWW } \\
(\mathrm{g})\end{array}$ & $\begin{array}{l}\mathrm{CT} \\
(\mathrm{mo})\end{array}$ & $\begin{array}{c}\text { TWW } \\
\text { (g) }\end{array}$ \\
\hline Ahe & May 2013 & 29.0 & 0.61 & 0.26 & 0.32 & 18 & $18.5 \pm 2.8$ & $831.9 \pm 190.6$ & 3 & $204.5 \pm 58.7$ \\
\hline Mangareva & May 2012 & 26.5 & 1.1 & 1.73 & 0.27 & 24 & $22.1 \pm 2.5$ & $\begin{array}{l}605.9 \pm 62.3 \\
698.8 \pm 12.3\end{array}$ & $\begin{array}{l}3 \\
6\end{array}$ & $\begin{array}{l}204.8 \pm 48.4 \\
124.4 \pm 18.9\end{array}$ \\
\hline
\end{tabular}

less abundant in Ahe than in Mangareva and settled only patchily on pearl oyster shells or on solitary ascidians (Microcosmus exasperatus). Many sponges (Dysidea sp.) were observed, with small crabs and polychaete worms settled between shells and ropes. In Mangareva, pearl oysters were colonized by a macrofaunal community composed mainly of ascidians (Didemnum sp., Microcosmus exasperatus, Herdmania momus), bivalves (Saccostrea cucullata, Pinctada maculata) and several erect or encrusting species of bryozoans. Many small crustaceans (Gammaridae and Isopoda) were also found.

In Mangareva, when comparing the epibiont biomass in CR units after 3 mo (CR3) and 6 mo (CR6) of colonization, we found it lower in CR6 but not significantly different from that of CR3 $(t=-2.68, \mathrm{df}=3, \mathrm{p}>$ 0.05). The dominant species in CR6 units was Didemnum sp., covering $60 \%$ of the net. It was less abundant in the CR3 units (coverage rate of $30 \%$ ), which were characterized by an abundance of tubiculous worms (Serpulidae, Sabellidae). All other organisms observed were present in both CR3 and CR6 units.

\section{Nutrient fluxes}

All fluxes measured were positive and correspond to DIN and SRP release in the water column (Fig. 5). DIN fluxes produced by CR units reached almost $200 \mu \mathrm{mol} \mathrm{h}^{-1}$ in Mangareva and $80 \mu \mathrm{mol} \mathrm{h}{ }^{-1}$ in Ahe. $\mathrm{NH}_{4}$ release always accounted for more than $60 \%$ of the total DIN fluxes. SRP fluxes were lower, with the smallest value (mean $\pm \mathrm{SD}: 0.99 \pm 0.52 \mu \mathrm{mol} \mathrm{h}^{-1}$ ) obtained for PO units in Ahe and the highest value $\left(49.68 \pm 13.23 \mu \mathrm{mol} \mathrm{h}^{-1}\right)$ obtained for CR units in Mangareva. For both DIN and SRP fluxes at the 2 sites, fluxes were significantly higher for CR units than for PO units (Table 4). Fluxes measured for CR3 and CR6 units in Mangareva were not significantly different for either DIN $(t=-0.84, \mathrm{df}=4, \mathrm{p}>0.1)$ or $\operatorname{SRP}(t=2.91, \mathrm{df}=1, \mathrm{p}>0.1)$.
Using the results obtained for nutrient release by PO units, we estimated that biofouling communities in Ahe and Mangareva contribute to 60 and $70 \%$, respectively, of the total DIN fluxes produced by CR units.
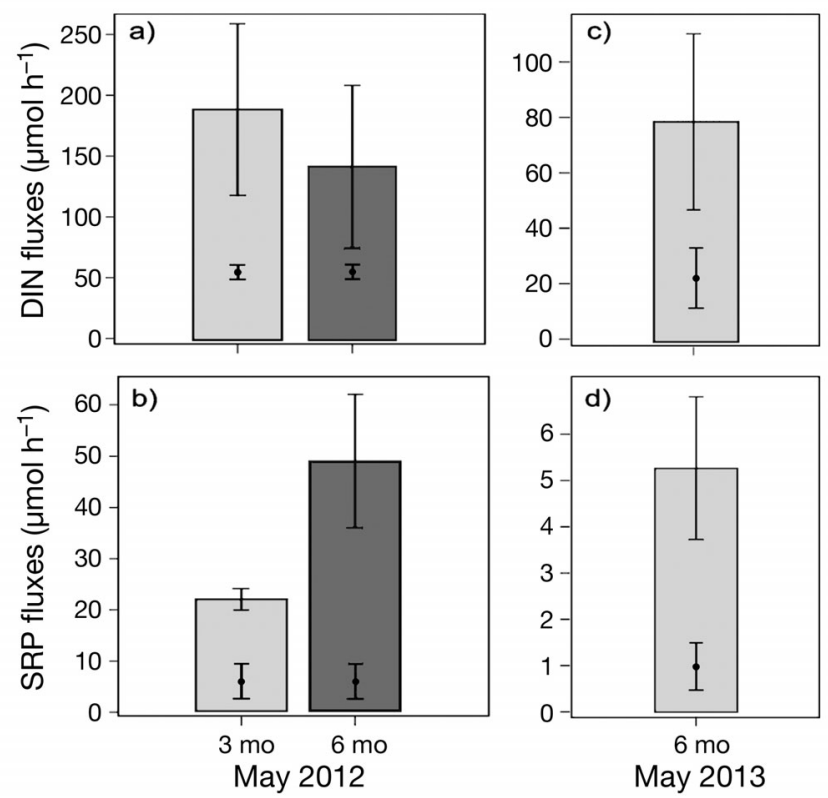

Fig. 5. Mean $( \pm \mathrm{SD})$ dissolved inorganic nitrogen (DIN) and soluble reactive phosphorus (SRP) fluxes measured in $(a, b)$ Mangareva and (c,d) Ahe for each treatment (light grey bar: ropes with 3 mo of biofouling development [CR3]; dark grey bar: ropes with 6 mo of biofouling development [CR6]; black dots: clean pearl oysters)

Table 4. Student's $t$-test for the effect of treatment (colonized ropes or cleaned pearl oysters) on measured fluxes in Ahe and Mangareva. Bold values are significant values at $\mathrm{p}<$ 0.05 . $\mathrm{DIN}=$ dissolved inorganic nitrogen $; \mathrm{SRP}=$ soluble reactive phosphorus

\begin{tabular}{|lrcccccc|}
\hline & \multicolumn{3}{c}{ DIN } & & & SRP & \\
Site & df & $t$ & p & df & $t$ & p \\
\hline Ahe & 11 & 5.9 & $\mathbf{2 0 . 0 0 1}$ & & 7 & 5.58 & $<\mathbf{0 . 0 0 1}$ \\
Mangareva & 6 & 5.6 & $<\mathbf{0 . 0 0 5}$ & 5 & 3.6 & $<\mathbf{0 . 0 5}$ \\
\hline
\end{tabular}




\section{DISCUSSION}

\section{Seasonal variations of nutrient fluxes}

During the annual monitoring in Tahiti, nutrient fluxes produced by pearl oysters (with or without biofouling communities) were mostly positive, indicating that culture acted as a source of nutrient for the water column. Factors which may influence nitrogen excretion by pearl oysters include individual size, temperature and trophic level (Yukihira et al. 1998, Saucedo et al. 2004, Mondal 2006). During this study, nutrient fluxes of clean pearl oysters (PO units) were constant over the year and were not correlated with the biomass of pearl oysters or with the environmental parameters recorded. Thus, the metabolism of pearl oysters seems to be maintained relatively independently of environmental conditions for the range of variations recorded. At 18,23 and $28^{\circ} \mathrm{C}$, Saucedo et al. (2004) also reported no variations of $\mathrm{NH}_{4}$ excretion efficiency for Pinctada mazatlanica. Over a similar range of temperatures $\left(23\right.$ to $\left.28^{\circ} \mathrm{C}\right)$, clearance rate and respiration have also been reported to be relatively independent of temperature for $P$. margaritifera and $P$. maxima, highlighting a probable acclimatization capacity of pearl oysters to moderate seasonal variations (Yukihira et al. 1998).

Whereas no temporal variation of fluxes was detected for clean pearl oysters, a sharp increase of DIN release and, to a lesser extent, SRP was observed for pearl oysters associated with biofouling communities (CR units) from 10 mo of colonization. As this increase of fluxes is not attributable to pearl oysters, whose activity remains stable, it could originate from the activity of biofouling communities accumulated on ropes (Mazouni et al. 2001, Richard et al. 2006, Jansen et al. 2011). Furthermore, it is now well established that in suspended culture, ropes are not only composed of the cultivated species and biofouling communities but also of detritus and organic material (Mazouni et al. 2001, Nizzoli et al. 2005, Richard et al. 2006, Jansen et al. 2011). In our study, a notable accumulation of organic material along the pearl oyster ropes started from November 2011, after heavy rainfall. In these 'associated fauna and organic matter' complexes, referred to as AFOM by Richard et al. (2006), mineralization of organic material may be a major nitrogen source (Richard et al. 2006, Nizzoli et al. 2011). Therefore, while few macrofouling organisms were observed on pearl oysters, it is possible that mineralization processes have also contributed to enhancing nutrient fluxes during this period. This assumption seems to be confirmed by the higher con- tribution of $\mathrm{NO}_{\mathrm{x}}$ to DIN fluxes in $\mathrm{CR}$ units compared with PO. Otherwise, during this period, the conjunction of higher temperature and elevation of DIN concentration in the water column is also likely to have stimulated microbial processes in AFOM complexes, further increasing mineralization and thus nutrient release (Sornin et al. 1986, Blackburn 1988, Boucher $\&$ Boucher-Rodoni 1988).

\section{Differences in pearl oyster metabolism between sites}

For the size class of pearl oysters considered in our study, $\mathrm{NH}_{4}$ fluxes produced by clean pearl oysters in Tahiti were lower than excretion values recorded by Pouvreau et al. (1998) or Yukihira et al. (2000), who found $\mathrm{NH}_{4}$ excretion varying from 1.1 to $4.4 \mathrm{\mu mol} \mathrm{h}^{-1}$ at 28 to $29^{\circ} \mathrm{C}$ for a $1 \mathrm{~g}$ flesh dry weight pearl oyster. At the other 2 sites, $\mathrm{NH}_{4}$ release reported in grams (dry weight) matched their results $(1.7 \pm 0.6 \mu \mathrm{mol} \mathrm{g}$ $\mathrm{h}^{-1}$ in Ahe and $2.5 \pm 1.0 \mu \mathrm{mol} \mathrm{g} \mathrm{h}{ }^{-1}$ in Mangareva). At this geographical scale, higher temperature did not lead to higher nutrient release (both DIN and SRP), since the highest fluxes were recorded in Mangareva, where the temperature was the lowest. This confirms that nutrient release through pearl oyster excretion not only is linked to temperature but also results from the interactions of different parameters (Saucedo et al. 2004, Mondal 2006,). Higher food availability in Mangareva, illustrated by the high chl a concentration recorded at this site, might explain the higher release rate measured (Yukihira et al. 1998). Otherwise, the discrepancy in nitrogen release between sites could also be related to variations of nitrogen resulting from diet rather than nitrogen from protein catabolism (Yukihira et al. 2000). This could explain the differences observed for nutrient fluxes between Ahe and Tahiti, since environmental conditions in Ahe were similar to those in Tahiti in 2012. To proceed, a better description of the trophic environment at each site, including heterotrophic plankton known to represent an important source of energy for pearl oysters (Fournier et al. 2012), is needed.

\section{Contribution of biofouling to nutrient fluxes}

Over the last decade, particular attention has focused on the effect that biofouling communities may exert on ecosystem processes (McKindsey et al. 2009, Jansen et al. 2011, Woods et al. 2012). Results of the present study at 2 sites exposed to a high level 
of biofouling confirmed the significant role these communities can play regarding nutrient regeneration in the water column around pearl oyster culture. Biofouling represented only 15 to $25 \%$ of the total biomass on experimental units but contributed up to $70 \%$ of the total DIN fluxes produced. The same result was obtained for SRP fluxes, which may be enhanced up to 7 times in the presence of biofouling.

The composition of biofouling communities has been shown to influence nutrient fluxes in suspended culture (Mazouni et al. 2001). Here, we failed to identify such an effect, since no significant difference in biomass or composition was observed for biofouling communities after 3 (CR3) and 6 (CR6) mo of colonization in Mangareva. Furthermore, nutrient fluxes recorded for CR3 and CR6 units were not significantly different. Conversely, wide differences were observed between fluxes produced by CR3 units from Ahe and Mangareva. DIN fluxes in Mangareva were twice as high as those in Ahe, while SRP fluxes were up to 15 times higher. This discrepancy may be primarily due to environmental conditions prevailing in the water column, which induced higher nutrient release by clean pearl oysters (PO units) in Mangareva. Moreover, biofouling composition might also contribute to explaining these differences. In Mangareva, biofouling communities were largely dominated by ascidians, which have already been shown to be a source of nutrients (Markus \& Lambert 1983) and biodeposits (McKindsey et al. 2009, Lee et al. 2012). The rearing method in Mangareva, where pearl oysters are maintained in nets (to reduce predation), could have favored the trapping of biodeposits and organic material more than ropes in Ahe. Mineralization processes of the organic matter accumulated in the rearing structures may thus have been more intensive in Mangareva and a major source of nutrient toward the water column.

\section{Overall impact of pearl oyster long-lines on nutrient dynamics in farming areas}

Pearl oyster long-lines significantly contributed to nutrient regeneration in the water column. Enhancement of nutrient availability for primary producers can result in increased primary production rate (Howarth 1988, Smaal 1991). In French Polynesia, where waters are oligotrophic and where primary production is highly dependent on internal physicochemical conditions (Charpy \& Blanchot 1998, Dufour et al. 2001), it can be postulated that by enhancing nutrient availability, the development of pearl oyster farming has a beneficial effect on primary production, thereby counteracting the negative effect it may have on phytoplankton (grazing pressure), as observed in other ecosystems (Nizzoli et al. 2005, 2011). In addition, whereas the N:P ratio calculated in the water column varied between 0.81 and 6.41 , the N:P ratio of fluxes sometimes reached 16:1. Such preferential nitrogen regeneration according to the Redfield ratio (16:1 for N:P, Redfield et al. 1963) may thus contribute to reducing the nitrogen limitation of these systems (Dufour \& Berland 1999). Otherwise, the major proportion of the nitrogen regenerated by colonized pearl oysters was in the form of $\mathrm{NH}_{4}$, which is preferentially assimilated by phytoplankton compared with $\mathrm{NO}_{\mathrm{X}}$ (Frost 1991). This nitrogen source could lead to a shift in the composition of phytoplankton communities, especially favoring the rapid growth of small phytoplankton (Howarth 1988, Prins et al. 1995).

To give a more realistic assessment of the impact of pearl oyster culture on the environment, we calculated the potential contribution of long-lines to primary production in Ahe. The theoretical nutrient requirement for primary production was calculated assuming that phytoplankton uptake of dissolved inorganic nutrients was within the Redfield ratio for growth (Redfield et al. 1963). Based on primary production presented by Lefebvre et al. (2012), this resulted in an estimation of nitrogen requirement of $423 \mathrm{mg} \mathrm{m}^{-2} \mathrm{~d}^{-1}$. With an estimated density of 40 pearl oysters per square meter at the farmed site, colonized ropes would thus supply around $70 \%$ of the nitrogen requirement for primary production, whereas cleaned pearl oysters would supply only $26 \%$. For comparison, benthic nutrient fluxes under farm influence in Ahe have been shown to contribute a maximum of $30 \%$ of the requirement for primary production (Gaertner-Mazouni et al. 2012). These results confirm the importance of nutrient regeneration within the water column in comparison with benthic fluxes and stress the necessity of studying in tandem the influence of the 2 compartments.

\section{CONCLUSIONS}

This first in situ study of nutrient fluxes at the interface between pearl oyster long-lines and the water column demonstrated the importance of not considering the cultivated organisms in isolation. In all 3 study lagoons, the contribution of biofouling communities to nutrient fluxes produced by cultivation units was indeed significant. The impact of pearl oyster 
farming on the water column displays wide spatial heterogeneity, and careful sampling is therefore required to derive reliable estimates of the overall functioning of these exploited tropical lagoons. Finally, our work showed that beyond the direct impact of biofouling on aquaculture end products, which usually require extensive handling, its role at the ecosystem scale needs further study to evaluate the sustainability of these ecosystems.

Acknowledgements. This study received financial support from the Agence Nationale de la Recherche within the framework of the program AGROBIOSHERE (ANR-11AGRO-006). E.L. was supported by a doctoral fellowship from the Ministère de l'Enseignement Supérieur et de la Recherche at the University of French Polynesia. We are grateful to the Direction des Ressources Marines of French Polynesia and to the pearl oyster farmers for their help in the field. We also thank the Institut de Recherche pour le Développement (IRD) Nouméa Centre (New Caledonia) for nutrient analysis and, finally, the 3 anonymous reviewers who provided comments which helped improve the manuscript.

\section{LITERATURE CITED}

Aminot A, Kérouel R (2004) Hydrologie des écosystèmes marins: paramètres et analyses. Editions de l'Ifremer, Plouzane

Asmus RM, Asmus H (1991) Mussel beds: limiting or promoting phytoplankton? J Exp Mar Biol Ecol 148:215-232

- Bacher C, Bioteau H, Chapelle A (1995) Modelling the impact of a cultivated oyster population on the nitrogen dynamics: the Thau Lagoon case (France). Ophelia 42: 29-54

Blackburn TH (1988) Benthic mineralization and bacterial production. In: Blackburn TH, Sørensen J (eds) Nitrogen cycling in coastal marine environments. SCOPE, John Wiley and Sons, Chichester, p 175-190

Boucher G, Boucher-Rodoni R (1988) In situ measurement of respiratory metabolism and nitrogen fluxes at the interface of oyster beds. Mar Ecol Prog Ser 44:229-238

Bouvy M, Dupuy C, Pagano M, Barani A, Charpy L (2012) Do human activities affect the picoplankton structure of the Ahe atoll lagoon (Tuamotu Archipelago, French Polynesia)? Mar Pollut Bull 65:516-524

> Charpy L, Blanchot J (1998) Photosynthetic picoplankton in French Polynesian atoll lagoons: estimation of taxa contribution to biomass and production by flow cytometry. Mar Ecol Prog Ser 162:57-70

Charpy L, Rodier M, Fournier J, Langlade MJ, GaertnerMazouni N (2012) Physical and chemical control of the phytopankton of Ahe lagoon, French Polynesia. Mar Pollut Bull 65:471-477

Charpy-Roubaud CJ, Charpy L, Cremoux JL (1990) Nutrient budget of the lagoonal waters in an open central South Pacific atoll (Tikehau, Tuamotu, French Polynesia). Mar Biol 107:67-73

Charpy-Roubaud C, Charpy L, Larkum A (2001) Atmospheric dinitrogen fixation by benthic communities of Tikehau Lagoon (Tuamotu Archipelago, French Polyne- sia) and its contribution to benthic primary production. Mar Biol 139:991-998

Cranford P, Dowd M, Grant J, Hargrave B, McGladdery S (2003) Ecosystem level effects of marine bivalve aquaculture. Can Tech Rep Fish Aquat Sci 2450:51-93

Crawford C, Macleod CK, Mitchell I (2003) Effects of shellfish farming on the benthic environment. Aquaculture 224:117-140

> Dame R, Libes S (1993) Oyster reefs and nutrient retention in tidal creeks. J Exp Mar Biol Ecol 171:251-258

Dufour P, Berland B (1999) Nutrient control of phytoplanktonic biomass in atoll lagoons and Pacific ocean waters: studies with factorial enrichment bioassays. J Exp Mar Biol Ecol 234:147-166

> Dufour P, Andrefouet S, Charpy L, Garcia N (2001) Atoll morphometry controls lagoon nutrient regime. Limnol Oceanogr 46:456-461

> Dumbauld BR, Ruesink JL, Rumrill SS (2009) The ecological role of bivalve shellfish aquaculture in the estuarine environment: a review with application to oyster and clam culture in west coast (USA) estuaries. Aquaculture 290:196-223

Faraway JJ (2002) Practical regression and ANOVA using R. http://cran.r-project.org/doc/contrib/Faraway-PRA.pdf (accessed 20 Jan 2014)

Forrest BM, Keeley NB, Hopkins G, Webb S, Clement D (2009) Bivalve aquaculture in estuaries: review and synthesis of oyster cultivation effects. Aquaculture 298:1-15

Fournier J, Dupuy C, Bouvy M, Couraudon-Réale M and others (2012) Pearl oysters Pinctada margaritifera grazing on natural plankton in Ahe atoll lagoon (Tuamotu archipelago, French Polynesia). Mar Pollut Bull 65: 490-499

Frost BW (1991) The role of grazing in nutrient-rich areas of the open sea. Limnol Oceanogr 36:1616-1630

Gaertner-Mazouni N, Lacoste E, Bodoy A, Peacock L and others (2012) Nutrient fluxes between water column and sediments: potential influence of the pearl oyster culture. Mar Pollut Bull 65:500-505

Giles H, Pilditch CA, Bell DG (2006) Sedimentation from mussel (Perna canaliculus) culture in the Firth of Thames, New Zealand: impacts on sediment oxygen and nutrient fluxes. Aquaculture 261:125-140

Holmes RM, Aminot A, Kérouel R, Hooker BA, Peterson BJ (1999) A simple and precise method for measuring ammonium in marine and freshwater ecosystems. Can J Fish Aquat Sci 56:1801-1808

> Howarth RW (1988) Nutrient limitation of net primary production in marine ecosystems. Annu Rev Ecol Syst 19: 89-110

Jansen HM, Strand Ø, Strohmeier T, Krogness C, Verdegem M, Smaal A (2011) Seasonal variability in nutrient regeneration by mussel Mytilus edulis rope culture in oligotrophic systems. Mar Ecol Prog Ser 431:137-149

> Kattner G (1999) Storage of dissolved inorganic nutrients in seawater: poisoning with mercuric chloride. Mar Chem 67:61-66

> Le Moullac G, Quéau I, Le Souchu P, Pouvreau S, Moal J, Le Coz JR, Samain JF (2007) Metabolic adjustments in the oyster Crassostrea gigas according to oxygen level and temperature. Mar Biol Res 3:357-366

Leblanc AR, Landry T, Miron G (2003) Fouling organisms of the blue mussel Mytilus edulis: their effect on nutrient uptake and release. J Shellfish Res 22:633-638

Lee JS, Kim SH, Kim YT, Hong SJ, Han JH, Hyun JH, Shin 
KH (2012) Influence of sea squirt (Halocynthia roretzi) aquaculture on benthic-pelagic coupling in coastal waters: a study of the South Sea in Korea. Estuar Coast Shelf Sci 99:10-20

Lefebvre S, Claquin P, Orvain F, Véron B, Charpy L (2012) Spatial and temporal dynamics of size-structured photosynthetic parameters (PAM) and primary production (13C) of pico- and nano-phytoplankton in an atoll lagoon. Mar Pollut Bull 65:478-489

> Markus JA, Lambert CC (1983) Urea and ammonia excretion by solitary ascidians. J Exp Mar Biol Ecol 66:1-10

Mazouni N (2004) Influence of suspended oyster cultures on nitrogen regeneration in a coastal lagoon (Thau, France). Mar Ecol Prog Ser 276:103-113

> Mazouni N, Gaertner JC, Deslous-Paoli JM (1998) Influence of oyster culture on water column characteristics in a coastal lagoon (Thau, France). Hydrobiologia 373/374: 149-156

Mazouni N, Gaertner JC, Deslous-Paoli JM (2001) Composition of biofouling communities on suspended oyster cultures: an in situ study of their interactions with the water column. Mar Ecol Prog Ser 214:93-102

- McKindsey CW, Lecuona M, Huot M, Weise AM (2009) Biodeposit production and benthic loading by farmed mussels and associated tunicate epifauna in Prince Edward Island. Aquaculture 295:44-51

Mitchell IM (2006) In situ biodeposition rates of Pacific oysters (Crassostrea gigas) on a marine farm in southern Tasmania (Australia). Aquaculture 257:194-203

Mondal SK (2006) Effect of temperature and body size on food utilization in marine pearl oyster Pinctada fucata (Bivalvia: Pteridae). Indian J Mar Sci 35:43-49

Newell RI (2004) Ecosystem influences of natural and cultivated populations of suspension-feeding bivalve molluscs: a review. J Shellfish Res 23:15-61

> Nizzoli D, Welsh DT, Bartoli M, Viaroli P (2005) Impacts of mussel (Mytilus galloprovincialis) farming on oxygen consumption and nutrient recycling in a eutrophic coastal lagoon. Hydrobiologia 550:183-198

Nizzoli D, Welsh D, Viaroli P (2011) Seasonal nitrogen and phosphorus dynamics during benthic clam and suspended mussel cultivation. Mar Pollut Bull 62:1276-1287

Picot B, Péna G, Casellas C, Bondon D, Bontoux J (1990) Interpretation of the seasonal variations of nutrient in a Mediterranean lagoon: Étang de Thau. Hydrobiologia 207:105-114

Pirazzoli PA (1984) Cartographie des hauts fonds par télédetection dans l'archipel des Gambier (Polynésie française). Espace Geogr 13:277-284

Pouvreau S, Prasil V (2001) Growth of the black-lip pearl oyster, Pinctada margaritifera, at nine culture sites of French Polynesia: synthesis of several sampling designs conducted between 1994 and 1999. Aquat Living Resour 14:155-163

Pouvreau S, Bodoy A, Buestel D (1998) Détermination du

Editorial responsibility: Gianluca Sara,

Palermo, Italy bilan énergétique chez l'huitre perlière, Pinctada margaritifera, et premier modèle écophysiologique de croissance dans le lagon d'atoll de Takapoto. Rapport IFREMER, Tahiti, French Polynesia, RI DRV 98-01

Prins TC, Escaravage V, Smaal AC, Peeters JCH (1995) Nutrient cycling and phytoplankton dynamics in relation to mussel grazing in a mesocosm experiment. Ophelia 41:289-315

$>$ Prins TC, Smaal AC, Dame RF (1997) A review of the feedbacks between bivalve grazing and ecosystem processes. Aquat Ecol 31:349-359

Redfield A, Ketchum BH, Richards FA (1963) The influence of organisms on the composition of sea water. In: Hill MN (ed) The sea. Interscience, New York, NY, p 26-77

Richard M, Archambault P, Thouzeau G, Desrosiers G (2006) Influence of suspended mussel lines on the biogeochemical fluxes in adjacent water in the Îles-de-laMadeleine (Quebec, Canada). Can J Fish Aquat Sci 63: 1198-1213

Saucedo PE, Ocampo L, Monteforte M, Bervera H (2004) Effect of temperature on oxygen consumption and ammonia excretion in the Calafia mother-of-pearl oyster, Pinctada mazatlanica (Hanley, 1856). Aquaculture 229: 377-387

Smaal AC (1991) The ecology and cultivation of mussels: new advances. Aquaculture 94:245-261

Sokal RR, Rohlf FJ (1995) Biometry: the principles and practice of statistics in biological sciences. WH Freeman, New York, NY

Sornin JM, Feuillet M, Héral M, Fardeau JC (1986) Influence des cultures d'huîtres Crassostrea gigas sur le cycle du phosphore en zone intertidale: rôle de la biodéposition. Oceanol Acta 9:313-322

Sussarellu R, Fabioux C, Le Moullac G (2010) Transcriptomic response of the Pacific oyster Crassostrea gigas to hypoxia. Mar Genomics 3:133-143

Talvard C (2011) La perliculture en 2010. Points Forts de la Polynésie Française No. 10, Institut de la Statistique de Polynésie Française, Papeete

- Welschmeyer NA (1994) Fluorometric analysis of chlorophyll $a$ in the presence of chlorophyll $b$ and pheopigments. Limnol Oceanogr 39:1985-1992

- Woods CMC, Floerl O, Hayden BJ (2012) Biofouling on Greenshell $^{\mathrm{TM}}$ mussel (Perna canaliculus) farms: a preliminary assessment and potential implications for sustainable aquaculture practices. Aquacult Int 20:537-557

Yukihira H, Klumpp DW, Lucas JS (1998) Comparative effects of microalgal species and food concentration on suspension feeding and energy budgets of the pearl oysters Pinctada margaritifera and P. maxima (Bivalvia: Pteriidae). Mar Ecol Prog Ser 171:71-84

Yukihira H, Lucas JS, Klumpp DW (2000) Comparative effects of temperature on suspension feeding and energy budgets of the pearl oysters Pinctada margaritifera and P. maxima. Mar Ecol Prog Ser 195:179-188

Submitted: September 11, 2013; Accepted: May 22, 2014 Proofs received from author(s): June 29, 2014 